\title{
繰返し軸方向力を受けるコンクリート充填鋼管部材の座屈挙動と エネルギー吸収能力に関する実験的研究
EXPERIMENTAL STUDY ON BUCKLING BEHAVIOR AND DISSIPATED ENERGY OF CONCRETE-FILLED TUBULAR MEMBERS UNDER CYCLIC AXIAL LOADING

\author{
河野昭彦*, 松井千秋**, 中島隆裕***, 高木潤一**** \\ Akihiko KAWANO, Chiaki MATSUI, Takahiro NAKAJIMA and Jun-ichi TAKAGI
}

\begin{abstract}
The objective of this paper is to demonstrate the aseismic capacity of concrete-filled tubular members subjected to cyclic axial load. About fifty specimens composed of cold-formed circular tubes and normal concrete were tested to quantify the number of loading cycles and the amount of dissipated energy upto breaking failure after local buckling. The test shows that both the failure cycle and the dissipated energy are fairly increased by filling the tube with concrete. The span of life of concrete-filled tubular member is affected by the diameter-thickness ratio, effective length and amplitude of axial displacement, and is successfully predicted by an estimation method proposed by authors. The dissipated energy upto failure can be also predicted by means of multiplying the number of loading cycles upto failure and the dissipated energy at each loading cycle. The dissipated energy and deformation capacity of concrete-filled tubular member with alternative diameter-thickness ratio and effective length are discussed from the results of test and theoretical estimation.
\end{abstract}

Keywords: concrete-filled tube, cyclic loading, flexural buckling, local buckling, energy dissipation capacity コンクリート充填鋼管，絽返し荷重，曲け座屈，局部座屈，エネルギー吸収能力

\section{1. 序}

本研究の目的は, 繰返し軸方向力を受けるコンクリー 卜充填円形鋼管部材の弾塑性性状とエネルギー吸収能力 を実験的に明らかにし，これによって耐震要素としての 性能を示すことである.

鋼管断面は, 絽返し軸力を受けると, 形鋼に比較して 薄肉であるため, 局部座屈後, 容易に破断に至る弱点が ある. しかし，コンクリートを充填することによって， この弱点が抑制可能で, 吸収エネルギ一の飛躍的な増大

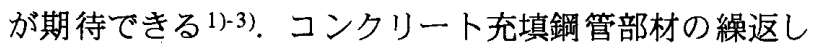
軸方向挙動の実験的研究が, Park $^{4)}$ と Goel ${ }^{5), 6)}$ によって行 われている。 Parkは, 短柱の単調圧縮・引張挙動と繰返 し挙動を比較した. Goelは, 角形鋼管をブレースとする 門形骨組に繰返し水平力を作用させ，充填コンクリート によって鋼管の破断が著しく遅延することを示した.

局部座屈後の破断則は, 純鉄骨部材について多少の研 究がある、松本等7) は, 各種の細長比を持つ中空円形鋼 管部材の繰返し軸力載荷実験を行い, Sherman ${ }^{8)}$ の破断則,
つまり部材の無次元化吸収エネルギーW / $\left(N_{y} \delta_{y}\right)$ が径厚 比によって定まるあるレベルに達したときに破断が生じ るとする条件の一般化を試みた．ここで， $N_{y}$ は鋼管の降 伏軸力, $\delta_{y}$ は軸力が $N_{y}$ での弾性軸変位である. 一方, 岩 井等9は, 山形鋼に繰返し軸力を作用させる実験から, 破 断までの吸収エネルギーは必ずしも一定ではないとした。 穂積等 ${ }^{10)}$ は, 角形鋼管の絽返し曲げ実験の局部座届部分 の応力履歴を基に，鋼管から採取した砂時計形試験片の 繰返し軸力載荷実験を行い, 亀裂発生が応力歪関係のス ケルトン領域の吸収エネルギーで予測可能とした. 桑村 11)は, 切欠き付き円柱形試験片の繰返し軸力載荷実験か ら，鋼材の亀裂発生メカニズムを調べ，丕振幅がある值 以上なら亀裂は延性破壊であり，このときの引張側累積 歪は単調引張での一様伸び(くびれが生じるまでの伸び) を越えることを示した. 従って, 脆性破壊を別とすれば, 比較的少数の加力サイクルで局部座屈する鋼管の初期龟 裂は延性破壊であり, 歪挙動で予測可能なことが示唆さ れる。

\footnotetext{
* 九州大学工学部建築学科 助教授 $\cdot$ 工博

** 九州大学工学部建築学科 教授. 工博

*** 侏)鹿島建設 工修

**** 九州大学工学部建築学科 大学院生
}

Assoc. Prof., Dept. of Architecture, Faculty of Engineering, Kyushu University, Dr. Eng.

Prof., Dept. of Architecture, Faculty of Engineering, Kyushu University, Dr. Eng.

Kajima Corporation, Ltd., M. Eng.

Graduate Student, Dept. of Architecture, Faculty of Engineering, Kyushu University 
本研究の試験体は，冷間成形鋼管を使用したコンクリ 一ト充填鋼管で，局部座屈挙動を調べるための短柱と， 曲げ座屈との連成を調べるための中・長柱がある．実験 結果を基に，コンクリート充填鋼管部材の軸方向挙動の 実用解析法, および短柱から長柱にわたる局部座屈後破 断条件を示す。さらに，破断までに吸収されるエネルギ 一の評価法を提案する.

\section{2. 実験概要}

\section{1 実験計画および試験体}

図1に示すように，コンクリート充填鋼管部材をピン 支持し，繰返し軸力を作用させる. 実験変数は，コンク リート充填の有無, 鋼管の径厚比 $D / T(D:$ 鋼管外径, $T$ : 管厚), 座屈長さと外径の比 $L_{k} / D$ ( $L_{k}$ : 座屈長さ), 軸力 載荷条件である.これらを表 1 に示す．ここでは， $L_{k} / D$ が 5 の試験体を短柱, 10を中柱, 20を長柱と呼ぶ.

試験体は，STK400の冷間成形鋼管で，外径は60.5mm， と101.6mmがある。図2に短柱試験体, 図3に中・長柱試 験体を示す. $D / T$ が50の試験体は，鋼管表面を旋盤で切 削して製作した，鋼管寸法を表 2 ，材料特性を表3に示 す。コンクリートは設計強度 $29.4 \mathrm{MPa}\left(300 \mathrm{~kg} / \mathrm{cm}^{2}\right)$ ，粗 骨材粒径 $20 \mathrm{~mm}$ 以下として表40ように調合した。表5a は,コンクリート充填短柱試験体の単調引張試験の結果, 表5bはコンクリート充填短柱（エンドプレート無し，材 長は外径の3倍）圧縮試験の結果で, 充填コンクリート のシリンダー強度も併せて示す.

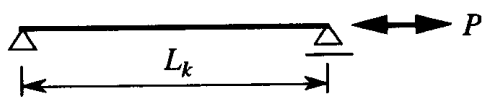

図1実験モデル

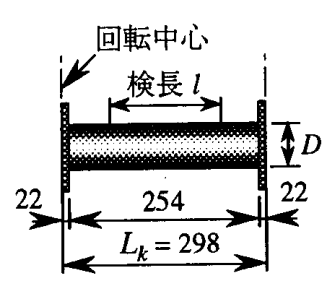

(a) $D=60.5 \mathrm{~mm}$

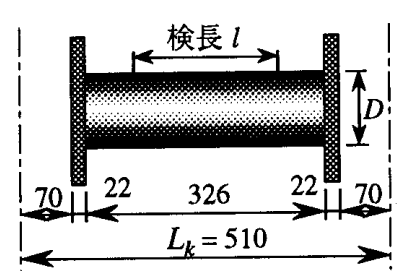

(b) $D=101.6 \mathrm{~mm}$
図2 短柱試験体

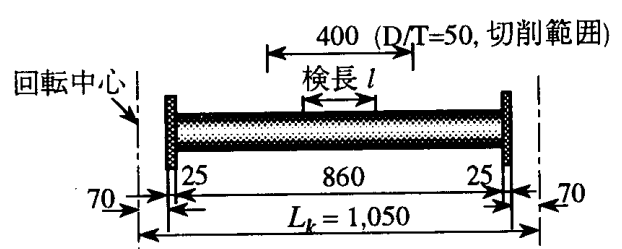

(a) $L_{k} / D=10, D=101.6 \mathrm{~mm}$

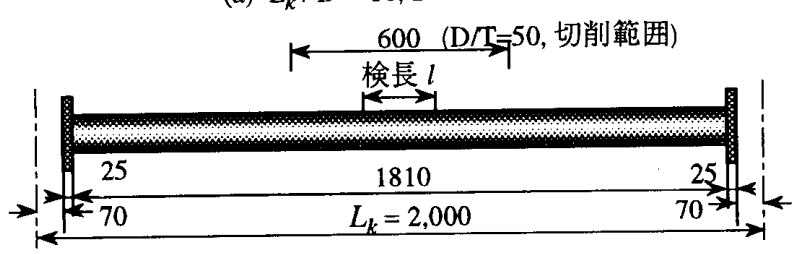

(b) $L_{k} / D=20, D=101.6 \mathrm{~mm}$

図3 中・長柱試験体
表1 試験体と実験変数

\begin{tabular}{|c|c|c|c|c|c|}
\hline \multicolumn{2}{|c|}{ 試非体 } & $\begin{array}{c}\text { コンクリ } \\
\text {-ト }\end{array}$ & $D / T^{*}$ & $L_{K} \mathcal{D}^{*}$ & 此荷条件 \\
\hline \multirow{4}{*}{$\begin{array}{c}\text { 短柱 } \\
\mathrm{D}= \\
60.5 \\
\mathrm{~mm}\end{array}$} & $\begin{array}{l}\text { SV2F10 } \\
\text { SV3F10 } \\
\text { SV5F10 }\end{array}$ & 無 & $\begin{array}{l}20(20.2) \\
30(29.1) \\
50(53.1) \\
\end{array}$ & $5(5.1)$ & 一定振幅土1.0\% \\
\hline & $\begin{array}{l}\text { SC2F10 } \\
\text { SC2F15 } \\
\text { SC2F20 }\end{array}$ & 充填 & $20(20.2)$ & $5(5.1)$ & $\begin{array}{l}\text { 一定振幅 } \pm 1.0 \% \\
\text { 一蛋振幅 } \pm 1.5 \% \\
\text { 一 } 2.0 \%\end{array}$ \\
\hline & $\begin{array}{l}\text { SC3F10 } \\
\text { SC3F15 } \\
\text { SC3F20 }\end{array}$ & 芜填 & $30(29.1)$ & $5(5.1)$ & $\begin{array}{l}\text { 二定振幅 } \pm 1.0 \% \\
\text { 二莡振幅士 } 1.5 \% \\
\text { 一定振幅 } \pm 2.0 \%\end{array}$ \\
\hline & $\begin{array}{l}\text { SC5F10 } \\
\text { SC5F15 } \\
\text { SC5F20 }\end{array}$ & 充填 & $50(53.1)$ & $5(5.1)$ & $\begin{array}{l}\text { 一定振幅 } \pm 1.0 \% \\
\text { 一定根幅士 } 1.5 \% \\
\text { 一定揊 } \pm 2.0 \%\end{array}$ \\
\hline \multirow{4}{*}{$\begin{array}{l}\text { 短柱 } \\
\mathrm{D}= \\
101.6 \\
\mathrm{~mm}\end{array}$} & $\begin{array}{l}\text { V2F10 } \\
\text { V3F10 } \\
\text { V5F10 } \\
\end{array}$ & 無 & $\begin{array}{l}20(18.6) \\
30(33.5) \\
50(49.6) \\
\end{array}$ & $5(5.0)$ & 一定振幅土 $1.0 \%$ \\
\hline & $\begin{array}{l}\mathrm{C} 2 \mathrm{~F} 15 \\
\mathrm{C} 2 \mathrm{~F} 20\end{array}$ & 涴填 & $20(18.6)$ & $5(5.0)$ & 一定握幅 $\pm 1.5 \%$ \\
\hline & $\begin{array}{l}\text { C3F10 } \\
\text { C3F15 } \\
\text { C3F20 } \\
\end{array}$ & 充填 & $30(33.5)$ & $5(5.0)$ & $\begin{array}{l}\text { 一定振幅 } \pm 1.0 \% \\
\text { 一定振幅士 } 1.5 \% \\
\text { 一定振幅 } \pm 2.0 \% \\
\end{array}$ \\
\hline & $\begin{array}{l}\text { C5F10 } \\
\text { C5F15 } \\
\text { C5F20 } \\
\end{array}$ & 充填 & $50(49.6)$ & $5(5.0)$ & $\begin{array}{l}\text { 一定振幅士 } 1.0 \% \\
\text { 一定振幅士 } 1.5 \% \\
\text { 一定振幅 } \pm 2.0 \%\end{array}$ \\
\hline \multirow{3}{*}{$\begin{array}{c}\text { 中柱 } \\
\mathrm{D}= \\
101.6 \\
\mathrm{~mm}\end{array}$} & $\begin{array}{l}\text { CS2F05 } \\
\text { CS2F07 } \\
\text { CS2F10 } \\
\text { CS2F20 } \\
\text { CS2FI }\end{array}$ & 充填 & $20(25.5)$ & $10(10.3)$ & 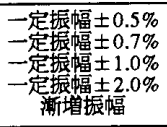 \\
\hline & $\begin{array}{c}\text { CS3F05 } \\
\text { CS3F07 } \\
\text { CS3F10 } \\
\text { CS3F20 } \\
\text { CS3FI }\end{array}$ & 充填 & $30(33.5)$ & $10(10.3)$ & 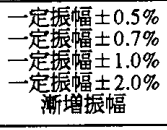 \\
\hline & $\begin{array}{c}\text { CS5F05 } \\
\text { CS5F07 } \\
\text { CS5F10 } \\
\text { CS5F20 } \\
\text { CS5FI }\end{array}$ & 夼填 & $50(46.5)$ & $10(10.3)$ & 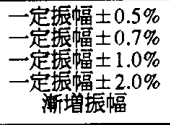 \\
\hline \multirow{3}{*}{$\begin{array}{c}\text { 長柱 } \\
\mathrm{D}= \\
101.6 \\
\mathrm{~mm}\end{array}$} & $\begin{array}{l}\text { CL2F05 } \\
\text { CL2F07 } \\
\text { CL2F10 } \\
\text { CL2F20 }\end{array}$ & 充填 & $20(25.5)$ & $20(19.7)$ & 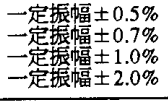 \\
\hline & $\begin{array}{l}\text { CL3F05 } \\
\text { CL3F07 } \\
\text { CL3F10 } \\
\text { CL3F20 }\end{array}$ & 充填 & $30(33.5)$ & $20(19.7)$ & $\begin{array}{l}\text { 一定振幅 } \pm 0.5 \% \\
\text { 一定势幅 } \pm 0.7 \% \\
\text { 一定振幅 } \pm 1.0 \% \\
\text { 一定振幅 } \pm 2.0 \% \\
\end{array}$ \\
\hline & $\begin{array}{l}\text { CL5F05 } \\
\text { CL5F07 } \\
\text { CL5F10 } \\
\text { CL5F20 }\end{array}$ & 充填 & $50(46.5)$ & $20(19.7)$ & $\begin{array}{l}\text { 一定振幅土 } 0.5 \% \\
\text { 一定振幅士0.7\% } \\
\text { 一定振幅士 } 1.0 \% \\
\text { 一定振幅土 } 2.0 \%\end{array}$ \\
\hline
\end{tabular}

*()内注実测值

表2 試験体の断面寸法と断面性能

\begin{tabular}{|c|c|c|c|c|c|}
\hline \multicolumn{2}{|c|}{ 試験体シリース } & $\begin{array}{l}\text { 外堡 } \\
D(\mathrm{~mm})\end{array}$ & $\begin{array}{l}\text { 管咠 } \\
T(\mathrm{~mm})\end{array}$ & $D / T$ & $\begin{array}{l}\text { 断面积 } \\
A\left(\mathrm{~mm}^{2}\right)\end{array}$ \\
\hline \multirow{2}{*}{ 短柱 } & $\begin{array}{l}\text { SV2, SC2 } \\
\text { SV3, SC3 } \\
\text { SV5, SC5 }\end{array}$ & $\begin{array}{l}60.5 \\
60.5 \\
58.5\end{array}$ & $\begin{array}{l}2.99 \\
2.08 \\
1.10\end{array}$ & $\begin{array}{l}20.2 \\
29.1 \\
53.1\end{array}$ & $\begin{array}{l}540 \\
382 \\
199 \\
\end{array}$ \\
\hline & $\begin{array}{l}\mathrm{V} 2, \mathrm{C} 2 \\
\mathrm{V3}, \mathrm{C3} \\
\mathrm{V} 5, \mathrm{C5}\end{array}$ & $\begin{array}{l}101.4 \\
101.4 \\
99.27 \\
\end{array}$ & $\begin{array}{l}5.44 \\
3.03 \\
2.00 \\
\end{array}$ & $\begin{array}{l}18.6 \\
33.5 \\
49.6 \\
\end{array}$ & $\begin{array}{l}1640 \\
936 \\
611 \\
\end{array}$ \\
\hline 中長柱 & $\begin{array}{l}\text { CS2, CL2 } 2 \\
\text { CS3, CL3 } \\
\text { CS5, CL5 }\end{array}$ & $\begin{array}{c}101.7 \\
101.6 \\
99.9\end{array}$ & $\begin{array}{l}3.95 \\
3.04 \\
2.16\end{array}$ & $\begin{array}{l}25.8 \\
33.5 \\
46.3\end{array}$ & $\begin{array}{l}1212 \\
940 \\
662\end{array}$ \\
\hline
\end{tabular}

表3 鋼管の機械的性政

\begin{tabular}{|c|c|c|c|c|c|}
\hline 試候方法 & $\begin{array}{l}\text { 試㧎体 } \\
\text { シリース }\end{array}$ & $\begin{array}{l}\text { 降伏応力 } \\
\sigma_{y}(\mathrm{MPa})\end{array}$ & $\begin{array}{l}\text { 最大応力 } \\
\sigma_{u}(\mathrm{MPa})\end{array}$ & $\begin{array}{c}\text { 一嘆伸ひ } \\
(\%)\end{array}$ & $\begin{array}{l}\text { 局部座属 } \\
\text { 発生䄳 }(\%)\end{array}$ \\
\hline \multirow{3}{*}{ 引張試駧 } & $\begin{array}{l}\text { SV2, SC2 } \\
\text { SV3, SC3 } \\
\text { SV5, SC5 }\end{array}$ & $\begin{array}{l}353 \\
324 \\
326\end{array}$ & $\begin{array}{l}423 \\
429 \\
427\end{array}$ & $\begin{array}{c}15.7 \\
15.9 \\
8.6 \\
\end{array}$ & $\begin{array}{l}- \\
-\end{array}$ \\
\hline & $\begin{array}{l}\text { V2, C2 } \\
\text { v3, C3 } \\
\text { v5, C5 }\end{array}$ & $\begin{array}{l}414 * \\
403 \\
373\end{array}$ & $\begin{array}{c}480^{*} \\
453 \\
434\end{array}$ & $\begin{array}{c}12.0 \\
9.3 \\
11.5\end{array}$ & - \\
\hline & $\begin{array}{l}\text { CS2, CL2 } \\
\text { CS3, CL3 } \\
\text { CS5, CL5 }\end{array}$ & $\begin{array}{l}422 * \\
372 \\
353\end{array}$ & $\begin{array}{l}497 * \\
449 \\
439\end{array}$ & $\begin{array}{l}11.8 \\
12.3 \\
11.1\end{array}$ & - \\
\hline \multirow{3}{*}{ 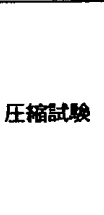 } & $\begin{array}{l}\text { SV2, SC2 } \\
\text { SV3, SC3 } \\
\text { SV5, SC5 }\end{array}$ & $\begin{array}{l}334 \\
309 \\
340\end{array}$ & $\begin{array}{l}407 \\
375 \\
351\end{array}$ & $\begin{array}{l}- \\
- \\
-\end{array}$ & $\begin{array}{l}2.9 \\
2.5 \\
0.55\end{array}$ \\
\hline & $\begin{array}{l}\mathrm{V} 2, \mathrm{C} 2 \\
\mathrm{~V} 3, \mathrm{C3} \\
\mathrm{v} 5, \mathrm{C} 5\end{array}$ & $\begin{array}{l}373 \\
398 \\
389\end{array}$ & $\begin{array}{l}459 \\
418 \\
397\end{array}$ & :- & $\begin{array}{l}2.5 \\
1.5 \\
0.32\end{array}$ \\
\hline & $\begin{array}{l}\text { CS2, CL2 } \\
\text { CS3, CL3 } \\
\text { CS5, CL5 }\end{array}$ & $\begin{array}{l}399 \\
348 \\
365\end{array}$ & $\begin{array}{l}460 \\
401 \\
383\end{array}$ & :- & $\begin{array}{l}2.1 \\
1.9 \\
1.1\end{array}$ \\
\hline
\end{tabular}

*JIS12号試験片によった. 
表4 コンクリートの調合

\begin{tabular}{|c|c|c|c|c|c|c|}
\hline 䰷㟪体 & $\begin{array}{c}\text { セxント } \\
\left(\mathrm{kg} / \mathrm{m}^{3}\right)\end{array}$ & $\begin{array}{c}\text { 細骨材 } \\
\left(\mathrm{kg} / \mathrm{m}^{3}\right)\end{array}$ & {$\left[\begin{array}{c}\text { 粗胃椗 } \\
\left(\mathrm{kg} / \mathrm{m}^{3}\right)\end{array}\right.$} & $\begin{array}{c}A E \text { 缡 } \\
\left(\mathrm{g} / \mathrm{m}^{3}\right)\end{array}$ & $\begin{array}{l}\text { W/C } \\
(\%)\end{array}$ & $\begin{array}{c}\text { スランフ } \\
(\mathrm{cm})\end{array}$ \\
\hline $\begin{array}{c}\text { 短柱 } \\
60.5 \mathrm{~mm}\end{array}$ & 325 & 784 & 1053 & 28 & 57 & 12 \\
\hline $\begin{array}{c}\text { 短柱 } \\
101.6 \mathrm{~mm}\end{array}$ & 296 & 804 & 1111 & 89 & 57 & 8 \\
\hline $\begin{array}{c}\text { 中長柱 } \\
101.6 \mathrm{~mm}\end{array}$ & 365 & 733 & 1039 & 91 & 45 & 6.3 \\
\hline
\end{tabular}

表5a コンクリート充填鋼管短柱の単睭引張特性

\begin{tabular}{|c|c|c|c|c|c|}
\hline $\begin{array}{l}\text { 試谽体 } \\
\text { シリース }\end{array}$ & $\begin{array}{l}N_{y} \\
(\mathrm{kN})\end{array}$ & $\begin{array}{l}N_{u} \\
(\mathrm{kN})\end{array}$ & $\begin{array}{c}\sigma_{y} \\
(\mathrm{MPa})\end{array}$ & $\underset{ }{\sigma_{u}}$ & $\begin{array}{c}\text { 一様伸ひ } \\
(\%)\end{array}$ \\
\hline $\begin{array}{l}\text { SC2 } \\
\text { SC3 } \\
\text { SC5 }\end{array}$ & $\begin{array}{l}202 \\
135 \\
71.9\end{array}$ & $\begin{array}{l}246 \\
178 \\
91.3\end{array}$ & $\begin{array}{l}374 \\
353 \\
361\end{array}$ & $\begin{array}{l}456 \\
466 \\
459\end{array}$ & $\begin{array}{l}15.1 \\
14.8 \\
7.44\end{array}$ \\
\hline $\begin{array}{l}\text { C2 } \\
\text { C3 } \\
\text { C5 }\end{array}$ & $\begin{array}{l}716 \\
402 \\
268\end{array}$ & $\begin{array}{l}854 \\
465 \\
308\end{array}$ & $\begin{array}{l}437 \\
429 \\
439\end{array}$ & $\begin{array}{l}521 \\
497 \\
504\end{array}$ & $\begin{array}{l}10.0 \\
9.18 \\
7.08\end{array}$ \\
\hline $\begin{array}{l}\text { CS2, CL2 } \\
\text { CS3, CL3 } \\
\text { CS5, CL5 }\end{array}$ & $\begin{array}{l}479 \\
378 \\
256\end{array}$ & $\begin{array}{l}590 \\
459 \\
319\end{array}$ & $\begin{array}{l}395 \\
402 \\
387\end{array}$ & $\begin{array}{l}487 \\
488 \\
482\end{array}$ & $\begin{array}{l}12.8 \\
8.49 \\
883\end{array}$ \\
\hline
\end{tabular}

$N_{y}$ : 降伏軸力, $N_{u}$ : 最大軸力; $\sigma_{y}=N_{y} / A_{s}, \sigma_{u}=N_{u} / A_{s}$.

表5b コンクリート充填鋼管短柱の単睭圧樎特性

\begin{tabular}{|c|c|c|c|c|c|}
\hline 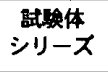 & $\begin{array}{l}N_{y} \\
(\mathrm{kN})\end{array}$ & $\begin{array}{c}N_{u} \\
(\mathrm{kN})\end{array}$ & $\begin{array}{c}\text { 局部座屈発生 } \\
\text { 歪(\%) }\end{array}$ & $\begin{array}{c}F_{c} \\
(\mathrm{MPa})\end{array}$ & $\begin{array}{l}\varepsilon_{c u} \\
(\%)\end{array}$ \\
\hline $\begin{array}{l}\text { SC2 } \\
\text { SC3 } \\
\text { SC5 }\end{array}$ & $\begin{array}{l}334 \\
309 \\
340\end{array}$ & $\begin{array}{l}407 \\
375 \\
351\end{array}$ & 測定せず & $\begin{array}{l}31.8 \\
34.7 \\
35.9\end{array}$ & $\begin{array}{l}0.20 \\
0.22 \\
0.22\end{array}$ \\
\hline $\begin{array}{l}\text { C2 } \\
\text { C3 } \\
\text { C5 }\end{array}$ & $\begin{array}{l}373 \\
398 \\
389\end{array}$ & $\begin{array}{l}459 \\
418 \\
397\end{array}$ & $\begin{array}{l}3.0 \\
2.1 \\
1.6\end{array}$ & $\begin{array}{l}40.0 \\
33.5 \\
37.0\end{array}$ & $\begin{array}{l}0.18 \\
0.21 \\
0.23\end{array}$ \\
\hline $\begin{array}{l}\text { CS2 } \\
\text { CS3 } \\
\text { CS5 }\end{array}$ & $\begin{array}{l}399 \\
348 \\
365\end{array}$ & $\begin{array}{l}460 \\
401 \\
383\end{array}$ & $\begin{array}{l}2.4 \\
2.3 \\
1.2\end{array}$ & 30.1 & 0.21 \\
\hline $\begin{array}{l}\text { CL2 } \\
\text { CL3 } \\
\text { CL5 }\end{array}$ & 同上 & 同上 & 同上 & $\begin{array}{l}33.7 \\
33.5 \\
46.1\end{array}$ & $\begin{array}{l}0.22 \\
0.24 \\
0.22\end{array}$ \\
\hline
\end{tabular}

$F_{c}$ : シリンダー王維蚛度， $\varepsilon_{c u}$ : シリンダー圧縮試歌での最大応力時歪.

\section{2 加力装置および測定方法}

ピン支点装置は片側が材軸方向に移動可能で，油圧ジ ヤッキの軸力はロードセル及びこの装置を通じて試験体 へ伝達される（図4）。中・長柱試験体は $5 \mathrm{~mm}$ の)偏心を 与え，危険断面が材中央に位置するのを確実にした．ピ ン支点装置は, 加力装置構面外への回転の夕が自由であ る. 油圧ジャッキは, 自動制御静的加力装置注2)によって 駆動した。

短柱試験体の軸変位は, 外径が $60.5 \mathrm{~mm} の$ 場合は材中央 の $160 \mathrm{~mm}$ （径厚比 50 では $185 \mathrm{~mm}$ ），外径が101.6mmでは $210 \mathrm{~mm}$ （径厚比 50 では $265 \mathrm{~mm}$ ）を検長 $l$ にとり, 軸対称 に配置した2台の変位計で測定した．中・長柱試験体は， 材長方向の変位をピン支点間 $L_{k}$ と材中央の検長 $l=210$ $\mathrm{mm})$ の 2 力所で測定した. 前者は加力制御用に，後者は 短柱試験体との関連を知るのに利用する.

\section{3 実験結果}

\subsection{1 軸方向荷重一変形関係}

図5は，外径が $60.5 \mathrm{~mm}$ の短柱試験体の軸力 $P$ と無次元 化軸変位 $\Delta l / l(\Delta l:$ 検長 $l$ の軸変位で 2台の変位計の平 均値）の関係を表す，図5(a)は，径厚比が20の中空鋼管 の場合である．履歷曲線は，一旦定常なループに収束す る傾向を示し，その後劣化して破断する．履歴曲線の劣 化は局部座屈変形の進展による．図5(b)，(c)は，径厚比

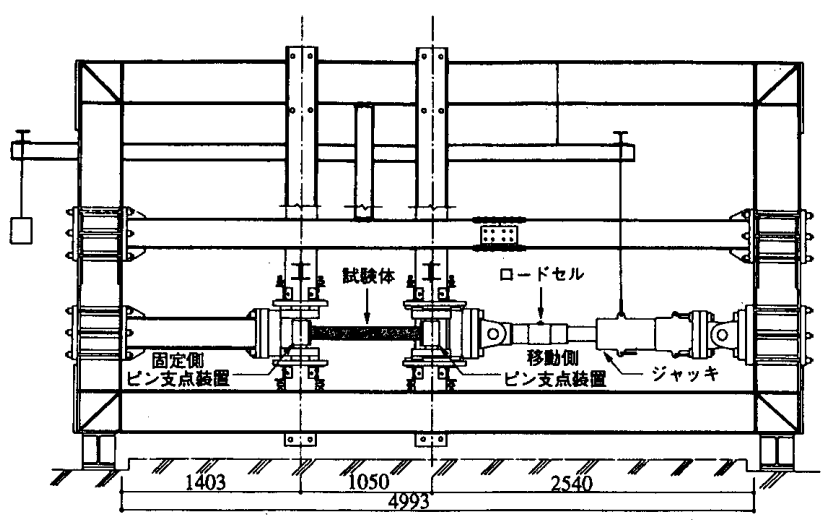

図4 加力装置

が30と50の中空鋼管の場合で, 局部座屈変形の進展つま り履歴曲線の劣化が早いことが分かる.

図5(d)〜 (f)は，コンクリートを充填したこと以外は， 図5(a) ( c) 之同一条件である.コンクリートを充填す ると, 履歷曲線の劣化が遅くなり, 加力サイクル数も飛 躍的に增大する．局部座屈は中空の場合とほぼ同様に比 較的早い時期に実験中観察されるが，座屈変形の進展が 遅延するのである.

図5(d)〜(1)は，径厚比が20，30および50のコンクリー 卜充填鋼管短柱で, $\Delta l / l$ が $\pm 1.0 \%, \pm 1.5 \%, \pm 2.0 \%$ の場 合を示す，軸変位振幅が大きいほど，履歴曲線の劣化が 早まり, 崩壊までの加力サイクル数が減少する.

図6は，外径が101.6mmの短柱の場合で，図5とほぼ同 じ条件である. 2 種類の外径寸法の短柱は，充填コンク リートの圧縮抵抗が処女サイクルでは有効だが，第2サ イクル以降は効果が半減し, 履歴曲線はスリップ型にな るなどほぼ同じ軸方向挙動を示している.

図7と図8は，コンクリート充填鋼管で，それぞれ $L_{k} / D$ が10および200場合を表す。図の軸変位 $\Delta L$ は, ピン支 点間での変位, $L$ は, ピン支点間距離からピン支点装置 とエンドプレート部分（長さ $95 \mathrm{~mm}$ ) を除いた長さとし た. 短柱と比較して履歴曲線の劣化が早い.

\subsection{2 局部座屈と亀裂破断}

図9は，一定軸変位振幅を受ける試験体の局部座屈発 生時と破断時の加力サイクルを示す．ただし，横軸は無 次元化軸変位の全振幅（例えば， $\pm 1.0 \%$ ときは $2.0 \%$ ) を表す．軸変位振幅がごく小さい場合を除いて，局部座 屈は早期に発生するが，破断までにはさらに多くの加力 サイクルを必要とするので，コンクリート充填鋼管部材 の終局限界を局部座屈発生時点とするのは不経済である.

\subsection{3吸収エネルギーの実験値}

図10(a)〜(d)は，破断までの吸収エネルギーWを，それ ぞれの引張降伏軸力 $N_{y}$ とそのときの弾性伸び $\delta_{y}$ で無次元 化して示す．図(a),(b)は,それぞれ外径が $60.5 \mathrm{~mm}$ と101.6 $\mathrm{mm}$ の短柱である. 図より, 径厚比と軸変位振幅が小さ いほどW/( $\left.N_{y} \delta_{y}\right)$ が大きいのが分かる. 軸変位振幅が增 


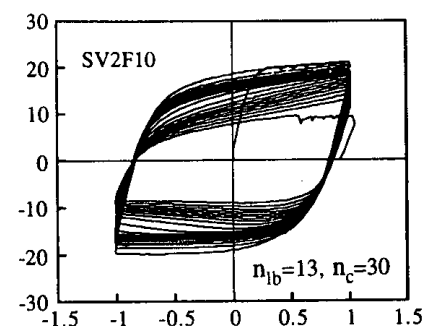

(a) 中空, $D / T=20, \Delta / l= \pm 1 \%$

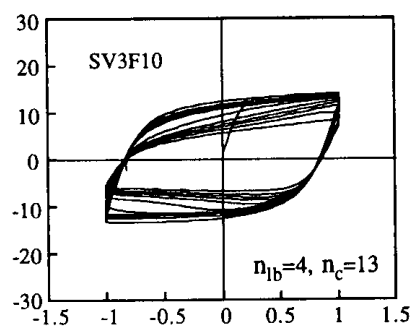

(b) 中空, $D / T=30, \Delta l / l= \pm 1 \%$

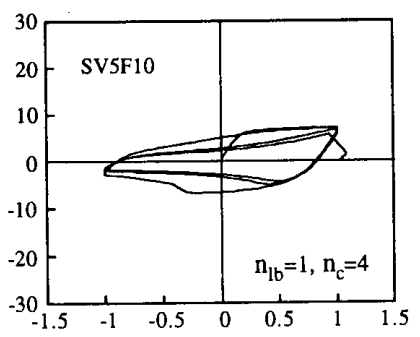

(c) 中空, $D / T=50, \Delta l / l= \pm 1 \%$

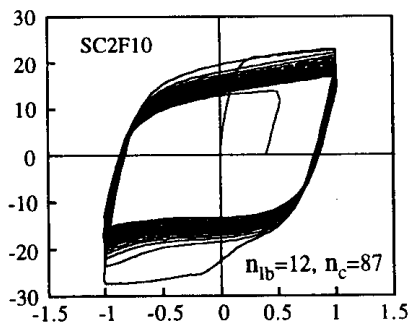

(d) 充填, $D / T=20, \Delta / / l= \pm 1 \%$

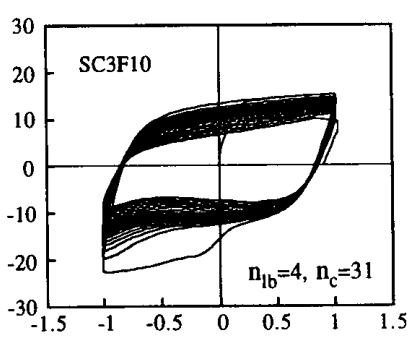

(e) 充填, $D / T=30, \Delta l / l= \pm 1 \%$

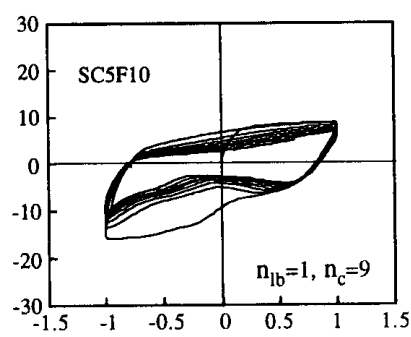

(f) 充填, $D / T=50, \Delta l / l= \pm 1 \%$

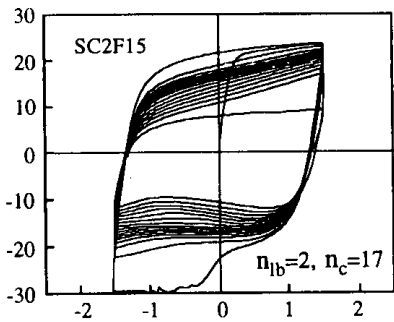

(g) 充填, $D / T=20, \Delta l / l= \pm 1.5 \%$

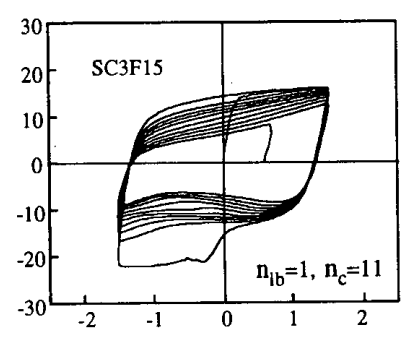

(h) 充填, $D / T=30, \Delta l / l= \pm 1.5 \%$

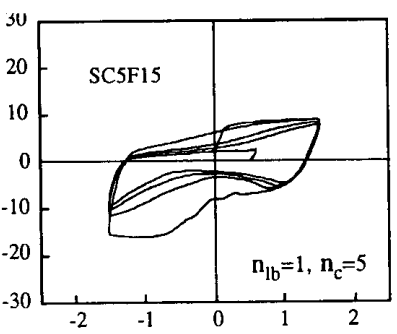

(i) 充填, $D / T=50, \Delta l / l= \pm 1.5 \%$

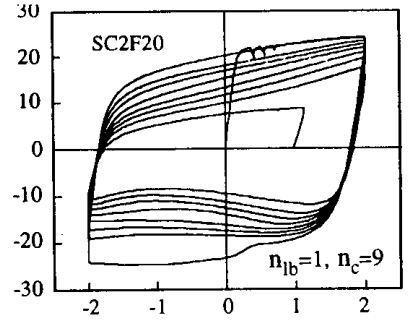

(j) 充填, $D / T=20, \Delta l / l= \pm 2 \%$

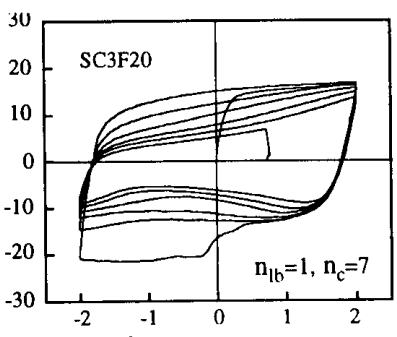

(k) 充填, $D / T=30, \Delta l / l= \pm 2 \%$

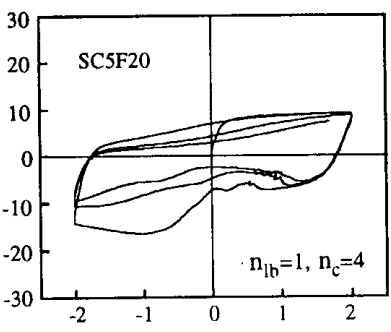

(l) 充填, $D / T=50, \Delta l / l= \pm 2 \%$

図5 短柱試験体の荷重変形関係 $\left(D=60.5 \mathrm{~mm}\right.$, 縦軸:荷重 $P(\mathrm{ton})$, 横軸:軸変位 $\Delta / l(\%), \mathrm{n}_{\mathrm{lb}}, \mathrm{n}_{\mathrm{c}}$ :局部座屈発生サイクル, 破断サイクル)

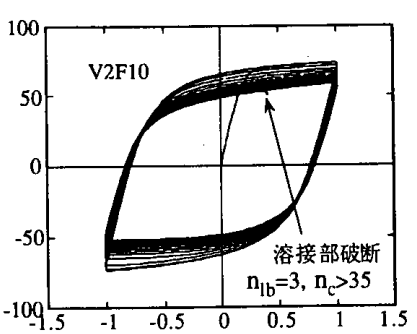

(a) 中空, $D / T=20, \Delta l / l= \pm 1 \%$

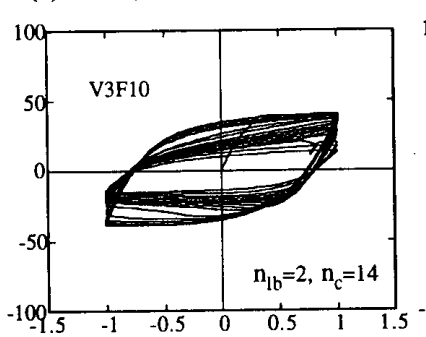

(b) 中空, $D / T=30, \Delta / l= \pm 1 \%$

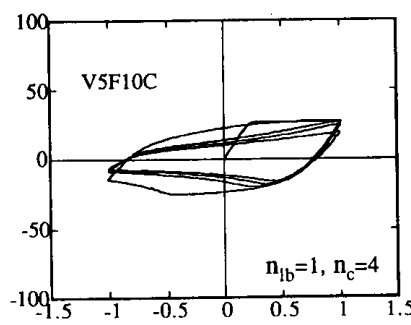

(c) 中空, $D / T=50, \Delta / / l= \pm 1 \%$

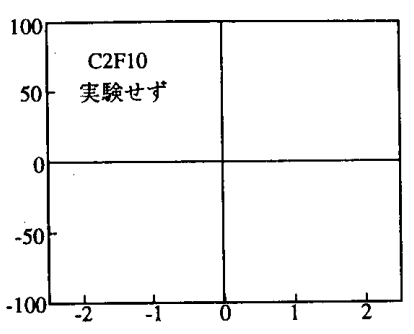

(d) 充填, $D / T=20, \Delta l / l= \pm 1 \%$

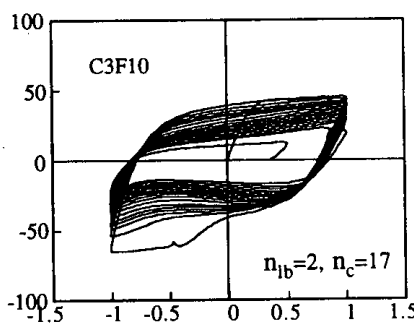

(e) 充填, $D / T=30, \Delta l / l= \pm 1 \%$

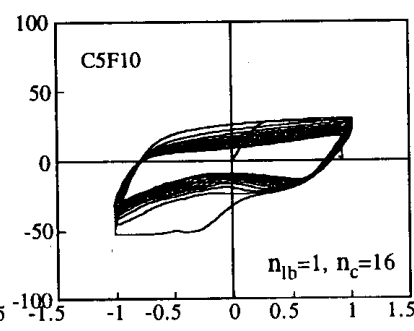

(f) 充填, $D / T=50, \Delta / / l= \pm 1 \%$

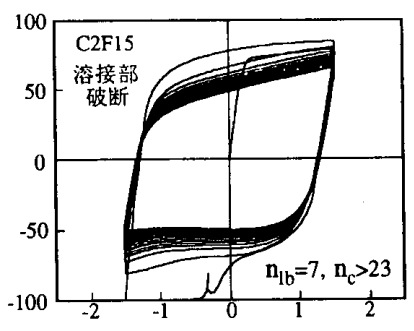

(g) 充填, $D / T=20, \Delta / / l= \pm 1.5 \%$

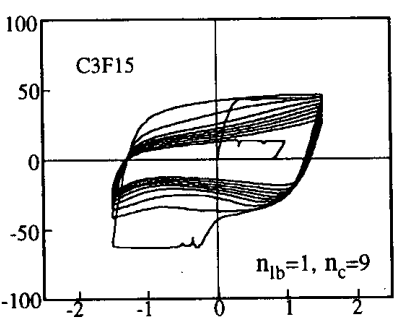

(h) 充填, $D / T=30, \Delta / l= \pm 1.5 \%$

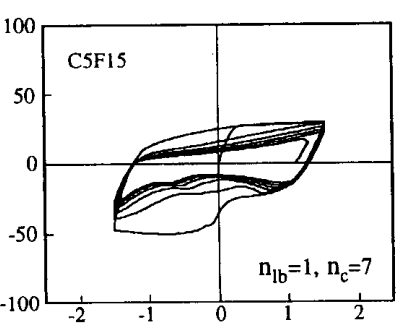

(i) 充填, $D / T=50, \Delta l / l= \pm 1.5 \%$

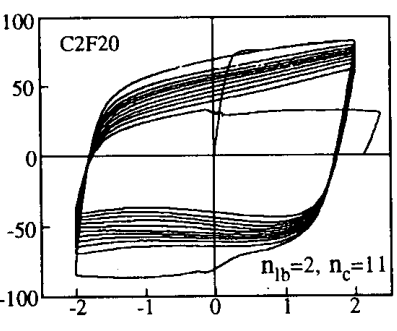

(j) 充填, $D / T=20, \Delta l / l= \pm 2 \%$

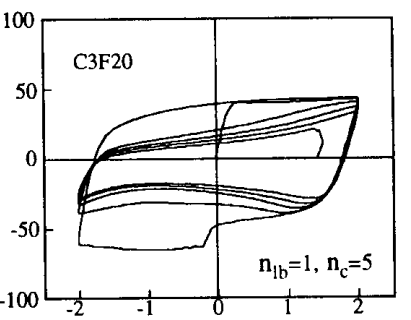

(k) 充填, $D / T=30, N / l= \pm 2 \%$

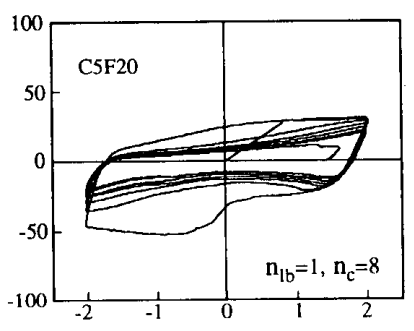

(1) 充填, $D / T=50, \Delta l / l= \pm 2 \%$

図6 短柱試験体の荷重変形関係 $\left(D=101.6 \mathrm{~mm}\right.$, 縦軸: 荷重 $P(\mathrm{ton})$, 横軸: 軸変位 $\Delta / l(\%), \mathrm{n}_{\mathrm{lb}}, \mathrm{n}_{\mathrm{c}}$ :局部座屈発生サイクル, 破断サイタル) 


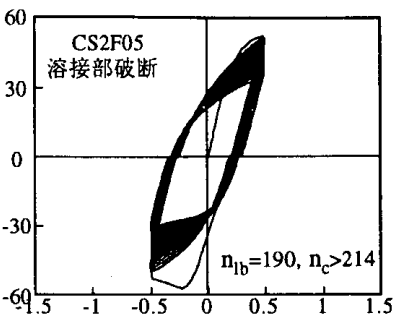

(a) 充填, $D / T=20, \Delta L / L= \pm 0.5 \%$

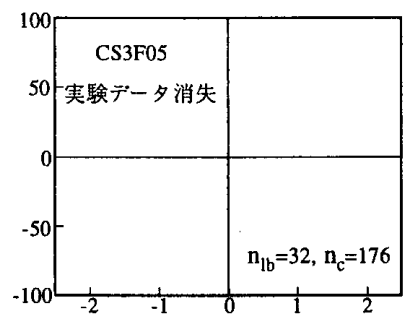

(b) 充填, $D / T=30, \Delta L / L= \pm 0.5 \%$

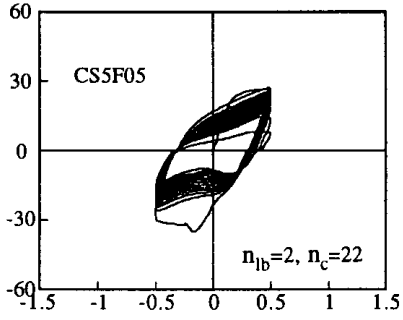

(c) 充填, $D / T=50, \Delta L / L= \pm 0.5 \%$

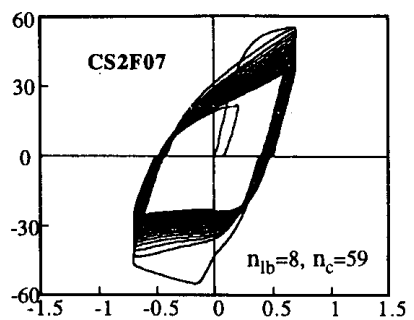

(d) 古填, $D / T=20, \Delta L / L= \pm 0.7 \%$

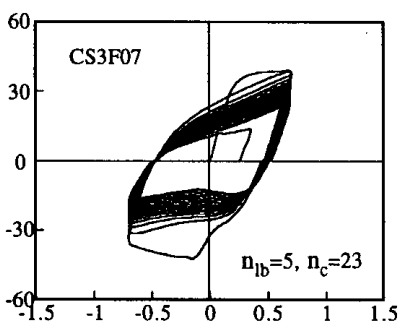

(e) 充填, $D / T=30, \Delta L / L= \pm 0.7 \%$

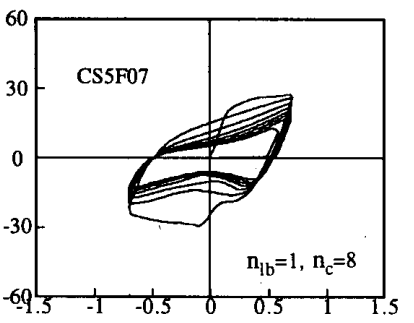

(f) 充填, $D / T=50, \Delta L / L= \pm 0.7 \%$

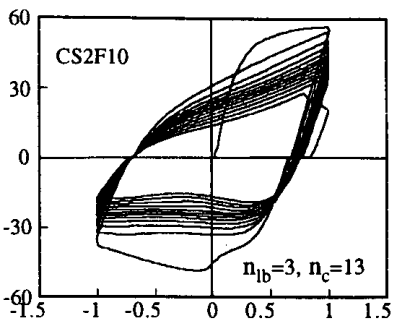

(g) 充填, $D / T=20, \Delta L / L= \pm 1 \%$

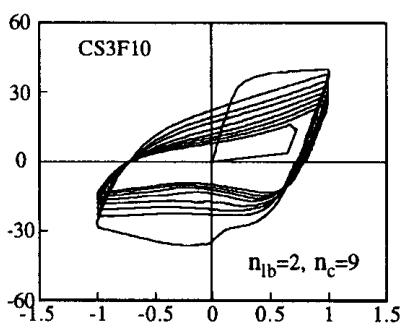

(h) 充填, $D / T=30, \Delta L / L= \pm 1 \%$

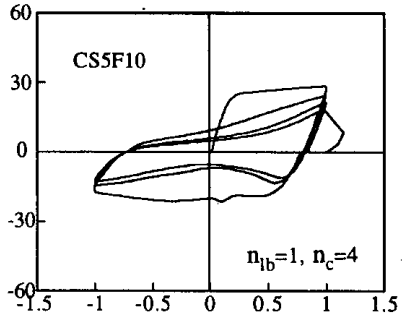

(i) 充填, $D / T=50, \Delta L / L= \pm 1 \%$

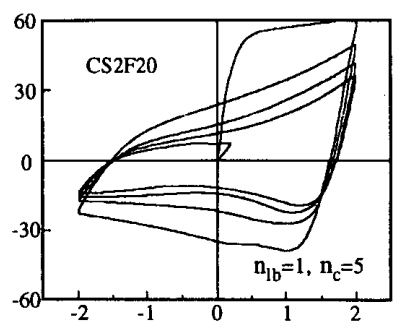

(j) 充填, $D / T=20, \Delta L / L= \pm 2 \%$

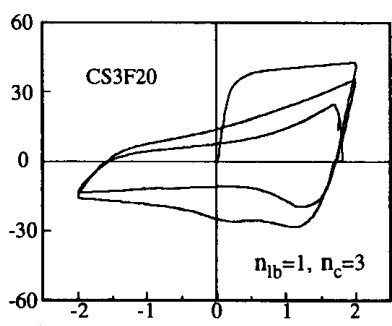

(k) 充填, $D / T=30, \Delta L / L= \pm 2 \%$

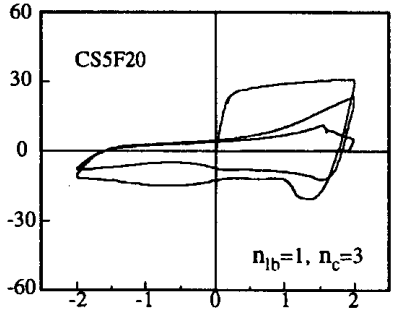

(l) 充填, $D / T=50, \Delta L / L= \pm 2 \%$

図7 中柱試験体の荷重変形関係 $\left(L_{k} / D=10\right.$, 縦軸:荷重 $P($ ton $)$, 横軸:軸変位 $\Delta L / L(\%), \mathrm{n}_{1 b}, \mathrm{n}_{\mathrm{c}}$ :局部座屈発生サイクル, 破断サイクル)

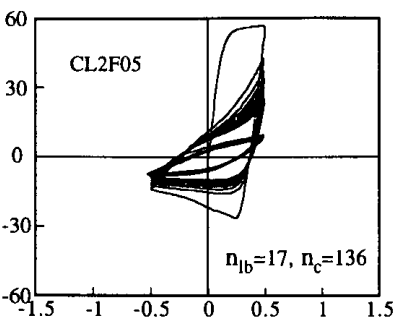

(a) 充填, $D / T=20, \Delta L / L= \pm 0.5 \%$

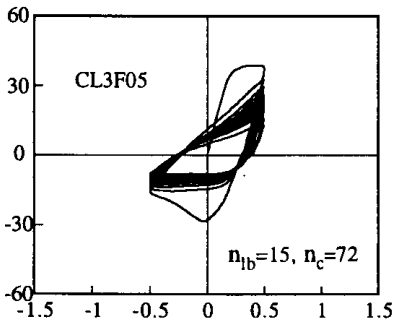

(b) 充填, $D / T=30, \Delta L / L= \pm 0.5 \%$

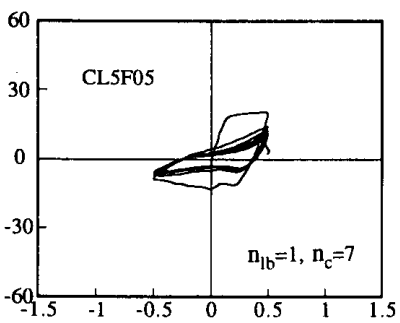

(c) 充填, $D / T=50, \Delta L / L= \pm 0.5 \%$

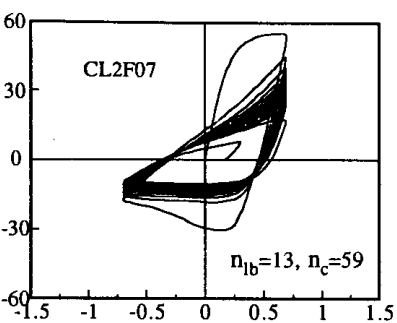

(d) 充填, $D / T=20, \Delta L / L= \pm 0.7 \%$

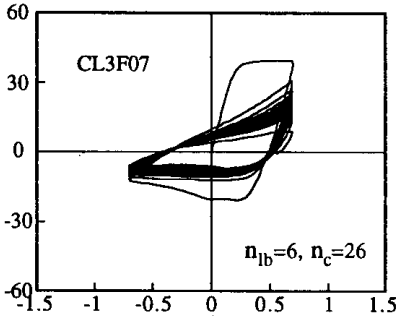

(e) 充填, $D / T=30, \Delta L / L= \pm 0.7 \%$

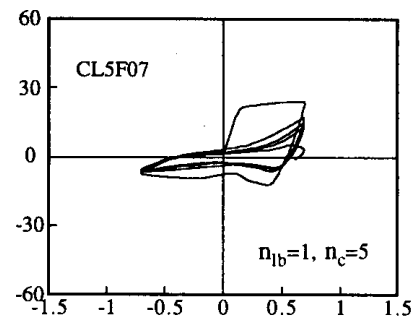

(f) 充填, $D / T=50, \Delta L / L= \pm 0.7 \%$

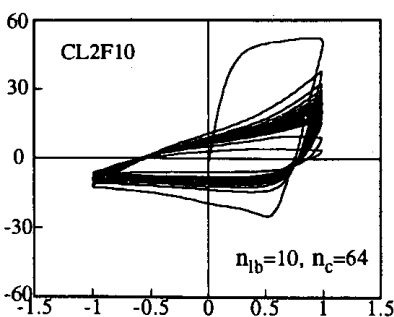

(g) 充填, $D / T=20, \Delta L / L= \pm 1 \%$

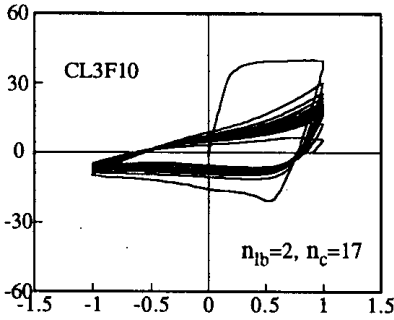

(h) 充填, $D / T=30, \Delta L / L= \pm 1 \%$

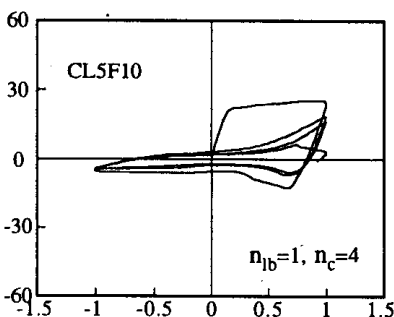

(i) 充填, $D / T=50, \Delta L / L= \pm 1 \%$

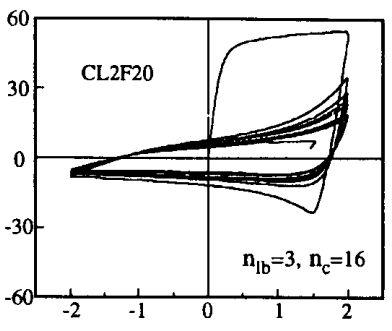

(j) 充填, $D / T=20, \Delta L / L= \pm 2 \%$

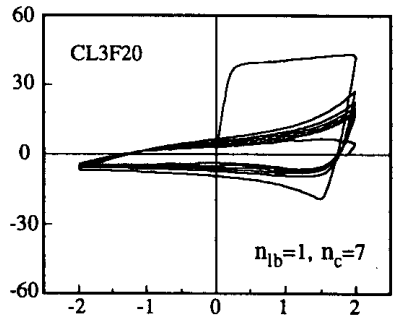

(k) 充填, $D / T=30, \Delta L / L= \pm 2 \%$

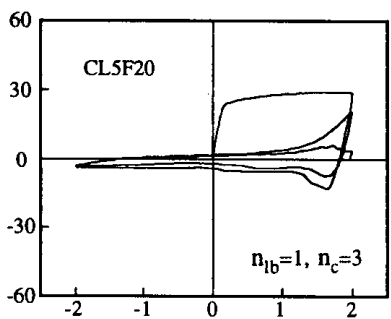

(1) 充填, $D / T=50, \Delta L / L= \pm 2 \%$

図8 長柱試験体の荷重変形関係 $\left(L_{k} / D=20\right.$, 縦軸: 荷重 $P(t o n)$, 横軸:軸変位 $\Delta L / L(\%), \mathrm{n}_{\mathrm{lb}}, \mathrm{n}_{\mathrm{c}}$ : 局部座屈発生サイクル, 破断サイクル) 


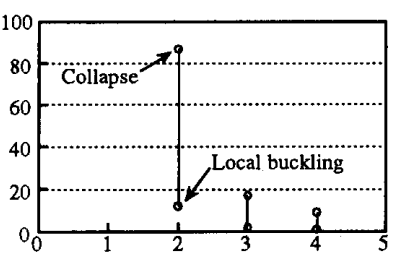

(a) $D / T=20, L k / D=5, D=60.5 \mathrm{~mm}$

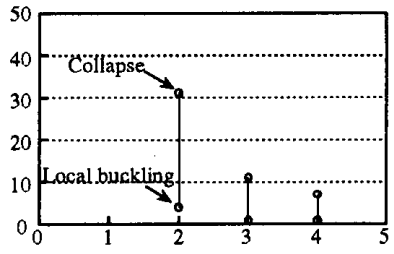

(b) $D / T=30, L x / D=5, D=60.5 \mathrm{~mm}$

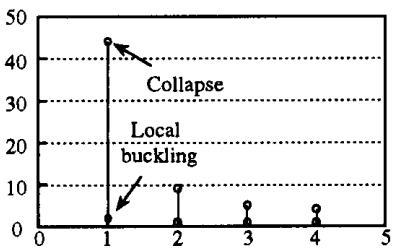

(c) $D / T=50, L K D=5, D=60.5 \mathrm{~mm}$

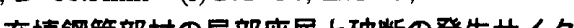

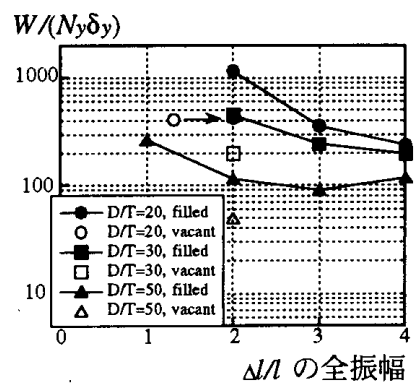

(a) $L k D=5, D=60.5 \mathrm{~mm}$

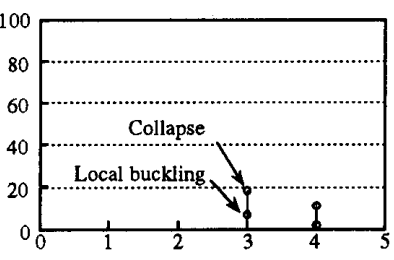

(d) $D / T=20, L K D=5, D=101.6 \mathrm{~mm}$

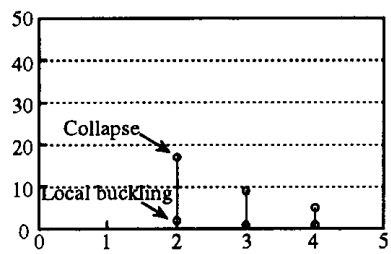

(e) $D / T=30, L K D=5, D=101.6 \mathrm{~mm}$

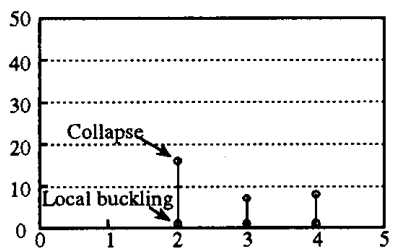

(f) $D / T=50, L K D=5, D=101.6 \mathrm{~mm}$

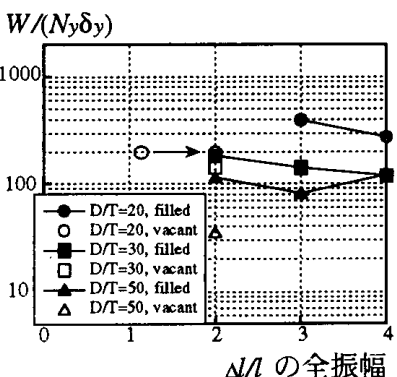

(b) $L k / D=5, D=101.6 \mathrm{~mm}$

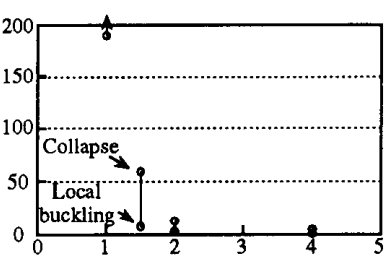

(g) $D / T=20, L k D=10$

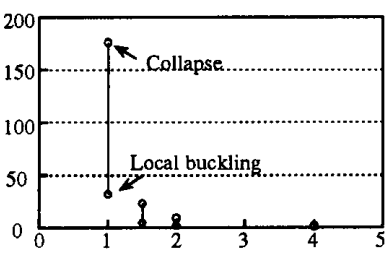

(h) $D / T=30, L k / D=10$

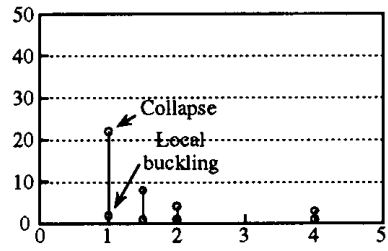

(i) $D / T=50, L K D=10$

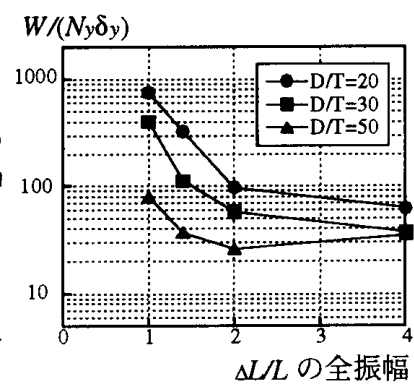

(c) $L k / D=10, D=101.6 \mathrm{~mm}$

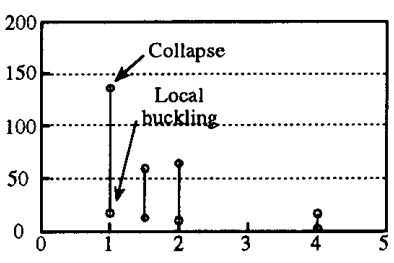

(j) $D / T=20, L k / D=20$

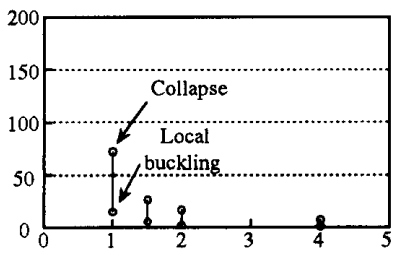

(k) $D / T=30, L K / D=20$

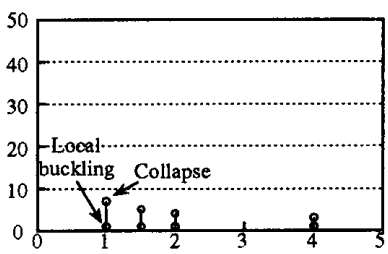

(1) $D / T=50, L k / D=20$

横軸 : 軸変位の全振幅(\%))

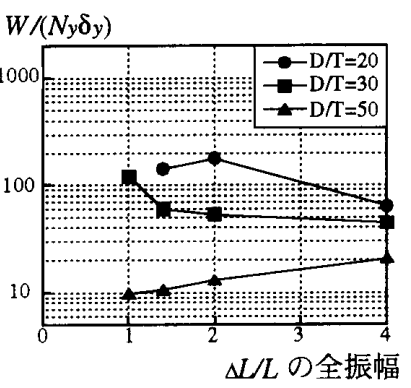

(d) $L k / D=20, D=101.6 \mathrm{~mm}$ 図10 無次元化吸収エネルギーの実験值

加するとW/( $\left.N_{y} \delta_{y}\right)$ は減少し, 一定値に漸近する傾向があ る. 図(a), (b)加ら, 軸変位振幅之径厚比が同一なら, 一 定の $W /\left(N_{y} \delta_{y}\right)$ が期待できそうである. 中空鋼管短柱は, 同一条件のコンクリート充填鋼管短柱に比較して，エネ ルギー吸収量が少ない。

$W /\left(N_{y} \delta_{y}\right)$ は, 引張降伏を基淮とした一種の換算塑性変 形倍率である. 短柱で径厚比が30の場合, $W /\left(N_{y} \delta_{y}\right)$ は100 以上, 200 場合, 200以上が期待できる. 一方, 径厚比が 50では100に満たない場合もある.さて，STK400の冷間

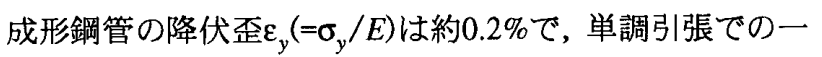
樣伸びは10\%程度であるので, 塑性変形倍率は50程度に なる. 従って, 繰返し軸力下のコンクリート充填鋼管短 柱は, 径厚比が 20 と 30 でそれぞれ単調引張時の4倍およ び2倍以上の変形性能があり，50はほぼ2倍前後になる. 図(c)，(d)は， $L_{k} / D か ゙ 10$ と20の場合で，短柱の場合より $W /\left(N_{y} \delta_{y}\right)$ が小さくなる.

\section{3. 数值解析による挙動の予測 \\ 3.1 解析手法と解析モデル}

解析手法は, 柱梁要素を用いた有限要素法である12),13).
図11に示す要素は, 平面保持が成立し, 断面の剛性と断 面力は断面区分法で与える. 要素剛性関係式は, 軸方向 変位を軸方向座標の1次式, たわみを3次式で近似し, せ

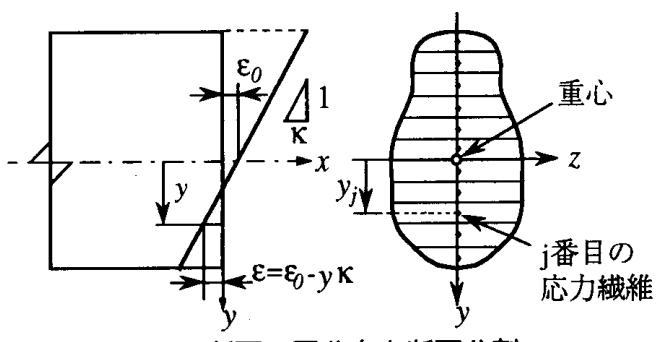

図11 断面の歪分布と断面分割

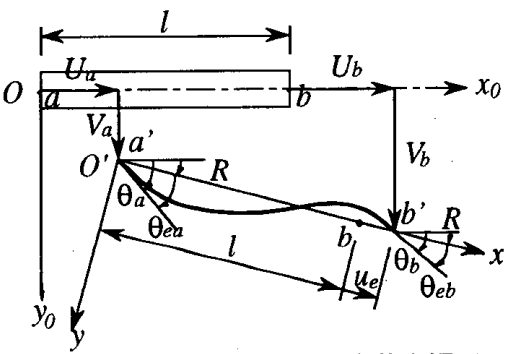

図12 柱梁要素の変形と移動座標系 


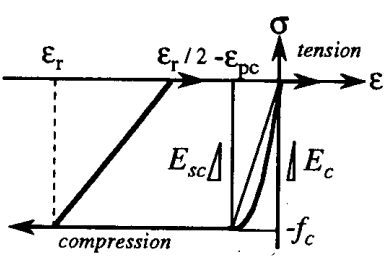

(a) コンクリート

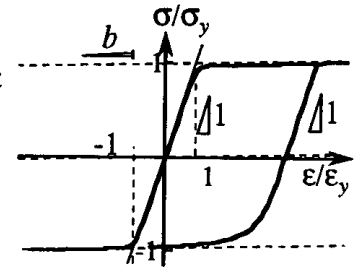

(b) 鋼管
図13 応力-㱏関係モテル
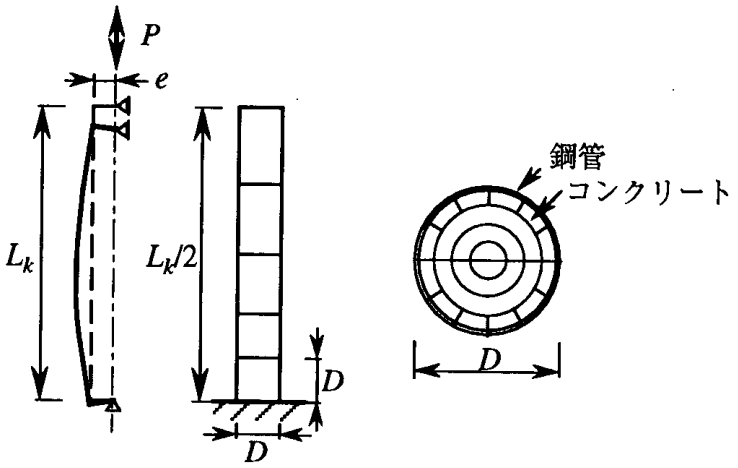

図14 解析モテル

ん断変形を無視して, ラグランジエ記述で定式化した. 図12に示すように，幾何非線形性の精度を保持するため 要素座標系を移動させた．増分解析は，荷重係数または 代表変位を制御変数として行う．増分の各段階では不釣 合節点力の解消を行う.

充填コンクリートと鋼管の相互作用，および鋼管の局 部座屈は無視する．充填コンクリートの応力歪関係は， 図13(a)のとおり，压縮強度まではPopovicsモデル14)を使 用し, その後一定で, 引張応力は無視する.

$$
\sigma=f_{c} \cdot \frac{r_{c}\left[\varepsilon / \varepsilon_{p c}\right]}{r_{c}-1+\left|\varepsilon / \varepsilon_{p c}\right|^{r_{c}}}\left(0 \geq \varepsilon \geq-\varepsilon_{p c}\right)
$$

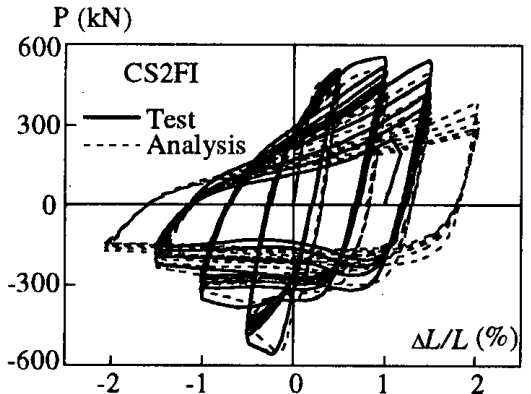

(a) $D / T=20, L k / D=10, D=101.6 \mathrm{~mm}$

$$
\mathrm{P}(\mathrm{kN})
$$

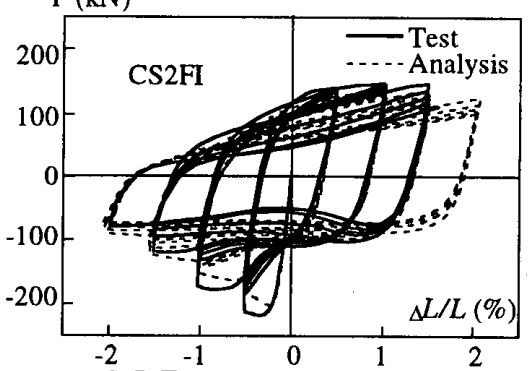

(d) $D / T=30, L K D=7, D=60.5 \mathrm{~mm}^{2}$

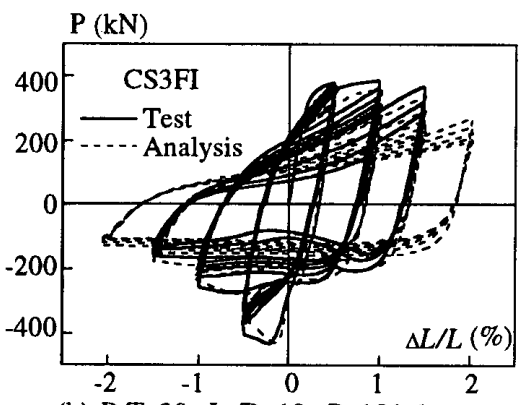

(b) $D / T=30, L k / D=10, D=101.6 \mathrm{~mm}$ $\mathrm{P}(\mathrm{kN})$

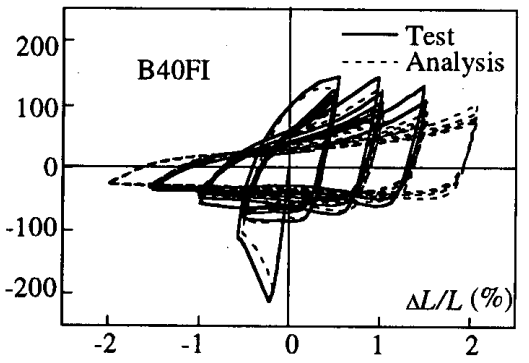

(e) $D / T=30, L K / D=13, D=60.5 \mathrm{~mm}$

$$
\begin{aligned}
& \sigma=-f_{c} \quad\left(-\varepsilon_{p c} \geq \varepsilon\right) \\
& r_{c}=\frac{E_{c}}{E_{c}-E_{s c}}, \quad E_{s c}=\frac{f_{c}}{\varepsilon_{p c}}
\end{aligned}
$$

$f_{c}$ は圧縮強度で, シリンダー圧縮試験によった. $\varepsilon_{p c}$ は最 大応力時の丕で $0.3 \%, E c$ はヤング係数で $28,000 \mathrm{MPa}$ 之 した. $E_{s c}$ は最大応力時の割線係数である。除荷曲線は, 歪軸上で反転点歪の 2 分の 1 を通る直線とした.

鋼管は，図13(b)のMenegotto-Pintoモデル15)とする.

$$
\begin{aligned}
& \sigma=\sigma_{y} \cdot\left[\frac{(1-b)\left(\varepsilon / \varepsilon_{y}\right)}{\left(1+\left|\varepsilon / \varepsilon_{y}\right|^{R_{m p}}\right)^{1 / R_{m p}}}+b\left(\frac{\varepsilon}{\varepsilon_{y}}\right)\right] \\
& b=\frac{E_{\text {hard }}}{E_{s}}
\end{aligned}
$$

$\sigma_{y}$ は降伏応力, $\varepsilon_{y}$ は降伏歪 $\left(=\sigma_{y} / E_{s}\right), E_{s}$ は鋼管のヤング係 数で, 200,000MPaとした. $E_{\text {hard }}$ は, 歪硬化域での接線係 数, $R_{m p}$ は 履歴曲線形状を決定する定数である. ここで は, 処女履歴曲線之反転後の後続履歴曲線を区別し, 歪 振幅が0.8\%を越えると移行することとした．処女履歴 曲線は, 中空鋼管の単調引張曲線を近似した. 後続履歴 曲線は，除荷域では接線係数をヤング率とする. 負荷域 では文献12)の引張与歪5\%からの反転曲線形状を近似し， モデル定数 $R_{m p}, b$ をそれぞれ0.8,0.002とした. さらに,

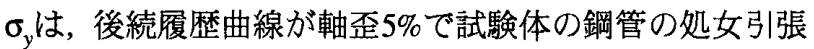
曲線と交差するように決定した．試験体の解析モデルを 図14に示す. 荷重の偏心がない試験体は, 加力点に最大 荷重の一万分の一程度の一定横力を作用させ，分岐点問 題を極限点問題に変えて解析した.

\section{2 実験挙動との比較}

図15に実験と解析によるコンクリート充填鋼管部材 の軸方向挙動の例を示す。図(a)〜(c)は, 外径101.6mm,

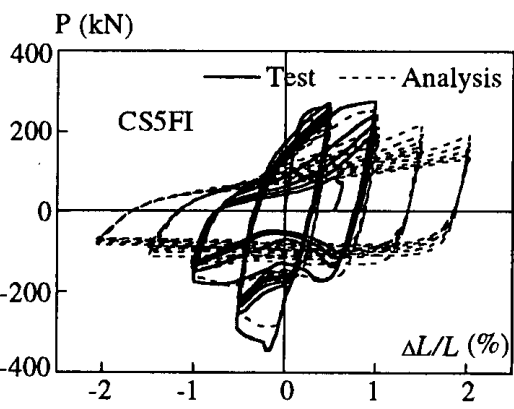

(c) $D / T=50, L / D=10, D=101.6 \mathrm{~mm}$ $\mathrm{P}(\mathrm{kN})$

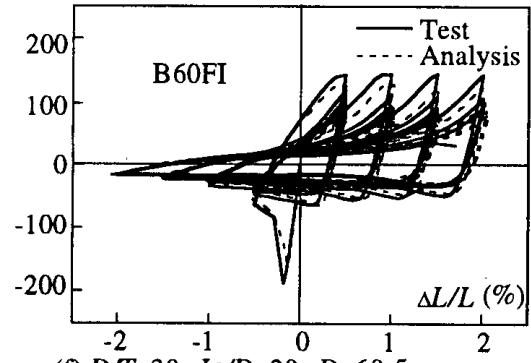

(f) $D / T=30, L K / D=20, D=60.5 \mathrm{~mm}$ 
$L_{k} / D=10$ の中柱の漸増変位振幅に対する結果で, それぞ れ径厚比が20，30，50を示している. 第 1 サイクルの引 張側反転点での軸力は, 解析値がやや低い. これは, 充 填コンクリートが鋼管の断面縮小を拘束する効果を無視 しているためである. また, 径厚比が大きいと, スリッ プ型履歴となるが, 局部座屈を無視している解析ではこ れを表現できない.しかし，ピークと反転点での軸力は おおむね予測できており，軸変位振幅が一定かまたは漸 增する条件では, 全体として本解析によって実験挙動を 予測できる.

図(d)〜(f)は, 外径が $60.5 \mathrm{~mm}$, 径厚比が300鋼管で, $L_{k} / D$ が約7，13，200場合2)を示す. 座屈長さの変化に対 しても解析の予測精度は変わらないのが分かる.

\section{4 破断までの加カサイクル数}

\subsection{D間緑変位振幅と破断加力サイクル数}

外径101.6mmの中・長柱試験体は, 部材中央の検長 210 $\mathrm{mm}$ (外径Dのほぼ2倍) での変位を測定している. そこ で, 曲げ座㞎時に圧縮縁となる側の変位振幅に着目し，2 $\mathrm{D}$ 間縁変位振幅 $A_{2 D}$ と呼ぶ，実験では，局部座屈および 充填コンクリートの圧壊がこの範囲に生じた. 図16は, 一定軸変位振幅下の外径が101.6mmの試験体の破断加力 サイクル数 $n_{c}$ と $A_{2 D}$ の関係である. $A_{2 D}$ は, 局部座屈変形 の進展が開始するまで一定の值に収束する傾向を示すの で,この值を読み取った. 図は, 座屈長さに無関係に, $n_{c}$ が径厚比毎に $A_{2 D}$ と強い相関它示している.また，変位 振幅がごく小さい場合を除けば, $n_{c}$ の対数值が $A_{2 D}$ とほぼ 線形関係にあるので, 次式を当てはめた.

$$
n_{c}=c_{1} \cdot \exp \left(c_{2} \cdot A_{2 D}\right)
$$

ここで, $c_{1}, c_{2}$ は, 経験定数であり, $D / T=20: c_{1}=180, c_{2}$ $=-37, D / T=30: c_{1}=60, c_{2}=-29, D / T=50: c_{1}=20, c_{2}=-$ 21 とした。 これらは実験の下限値を衫らうと共に, $A_{2 D}$ が14\%のときに $n_{c}$ が1になるように定めた. 式(3)の適用 範囲と定数值は, 鋼管の材質, 製法, サイズに対してさら に検討を要する. また, 変位振幅がごく小さい場合は局 部座屈発生が遅延し, 破断加力サイクル数が上式の予測 をかなり越える．この点も検討の余地がある.

\subsection{D間緑変位振幅と軸変位振幅の関係}

各種の座屈長さを持つ部材に対して, 軸変位振幅から $2 \mathrm{D}$ 間縁変位振幅 $A_{2 D}$ を予測できれば，それぞれの座届 長さに対する破断加力サイクル数 $n_{c}$ が軸変位振幅から予 測できる. 図 17 は, $A_{2 D}$ と軸変位振幅の関係を 3 節の解析 で求めた． $A_{2 D}$ は加力サイクルが進むと一定の值に収斂 するので, 各軸変位振幅レベルで 5 回繰返したときの最 終加力サイクルの值とした. 径厚比にはほとんど影響さ れなかったので, 図は径厚比が30の場合を示している。

同図から, $A_{2 D}$ 上軸変位振幅の関係は, 座屈長さによっ て大きく変わるのが分かる．座屈長さが非常に短いか, あるいは長いと, $A_{2 D}$ は小さくなり, 破断しにくいことが 予想される，これは文献2)の実験結果と一致する.

\section{3 破断加力サイクル数の予測}

一定軸変位振幅下でのコンクリート充填鋼管部材の破 断加力サイクル数 $n_{c}$ は, 次のように求められる. 図17か ら所定の軸変位振幅に対する $A_{2 D}$ を読み取る。次に図 16 から, $A_{2 D}$ に対応する $n_{c}$ を読み取る。

軸変位振幅が漸増する場合は, Miner による累積損賃 則16)を適用することにする.

$$
D(m)=\sum_{i=1}^{m} \frac{n_{i}}{n_{c i}}=1
$$

ここで, $n_{i}$ はある軸変位振幅レベルでの加力サイクル数, $n_{c i}$ はその振幅レベルでの破断加力サイクル数, $m$ は各種 振幅レベルの個数を表す. Miner則では $D(m)$ を累積損傷 率としこれが1に達したときに破断が生じるとする。

図18は，以上を外径が101.6mmの $L_{k} / D か ゙ 100$ 試験体 と, 外径が $60.5 \mathrm{~mm}$ で各種の座屈長さを持つ試験体 ${ }^{2} に$ 適 用した結果である，多少の誤差はあるものの，おおむね 安全側で実験値を予測できるのが分かる。

\section{5. エネルギー吸収能力}

\section{1 破断までの吸収エネルギーの予測}

破断加力サイクル数 $n_{c}$ が予測可能であれば，加力サイ クル当たりの吸収エネルギーが与えられると，これらの 積で破断までのエネルギ一吸収量が求められる。図19 は, 3 節の解析で, 各種の $L_{k} / D$ に対する加力サイクル当 たりの吸収エネルギー $W_{0}$ を求めた結果である. 図では,

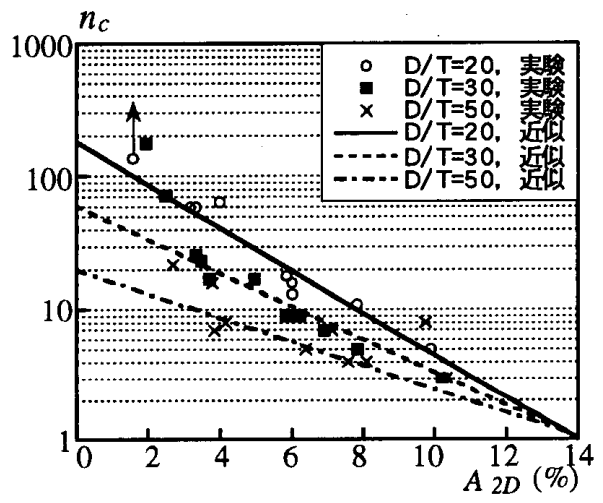

図16 崩壊加カサイクルと2D間緑変位振幅

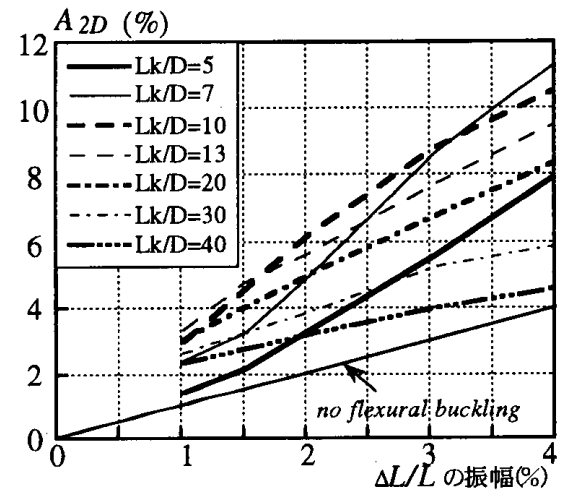

図17 2D間緑変位振幅と軸変位振幅

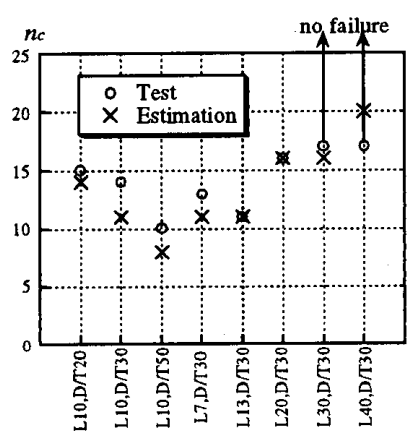

図18 漸増变位振幅での崩壊予測 


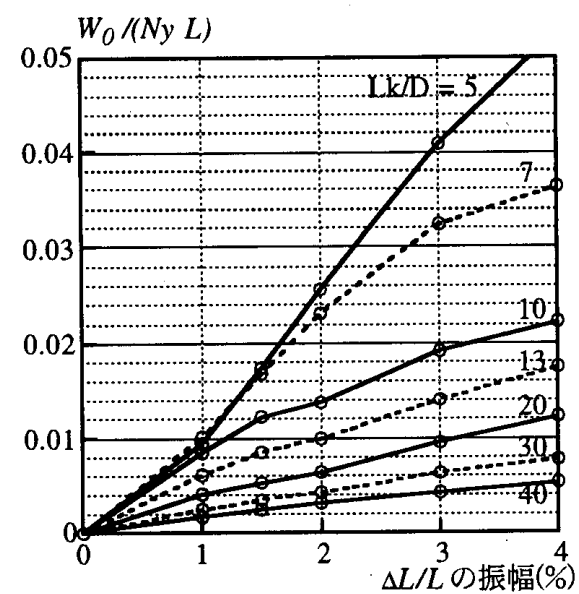

図19 加カサイクル当たり吸収エネルギー

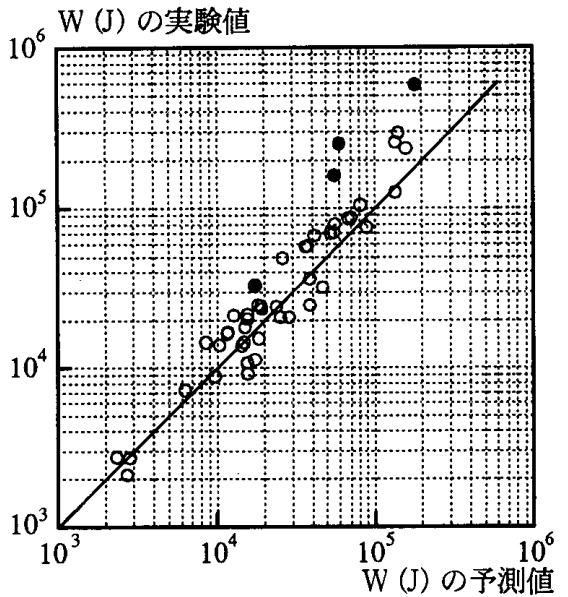

図20吸収エネルギーの実験值と予測值

$W_{0}$ を $N_{y} L$ で無次元化している. $W_{0}$ は軸変位振幅の各 レベルで5回繰返したときの各振幅レベルの最終サイク ルの値とした。また，各種の径厚比に対して差がなかっ たので, 径厚比30の結果を示している.

図20は, 本研究と文献2)の試験体について, 破断まで の吸収エネルギー $W$ の実験値と予測値を比較している. W の予測值は，4.3項の手順で得られた破断加力サイク ル数 $n_{c}$ と図19による $W_{0} /\left(N_{y} L\right)$, および中空鋼管の引張 降伏軸力 $N_{y}$ と塑性変形が可能な材長 $L$ 乗じて求めた. 漸増変位振幅の場合は, Miner 則を使用した。軸変位振 幅が1.0\%のもの（黒丸印）は, 局部座屈発生が遅く, 破 断加力サイクルが予測より多いのでかなり安全側に評価 されている。これらを除いた全試験体の吸収エネルギ一 の実験値と予測値の比は, 平均で 1.21 , 変動係数は 13.8\%になっており，ここでの予测方法は工学的使用に 耐えるものと考えられる.

\section{2 吸収エネルギーに及ぼす座屈長さと軸力䡛荷条件}

以上の予測方法を用いて，破断加力サイクル数 $n_{c}$ と破 断までの吸収エネルギーWに対する座屈長さの影響を調 べた. 図21は, 横軸を $L_{k} / D$ とし, 各種の径厚比に対する $n_{c}$ を示す. 図(a),（b)は軸変位振幅が2\%と4\%の場合を表

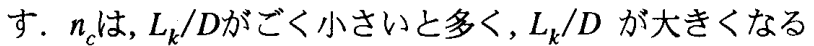
之, 一旦 $L_{k} / D=10$ 前後で最少となって, 再び増加する. $n_{c}$ は, $A_{2 D}$ に関係しており, $L_{k} / D=10$ 前後で $A_{2 D}$ がもっと も大きいことを意味する. $L_{k} / D$ がごく小さい場合は, 座屈長さが短いので曲げ座屈変形が小さいため $A_{2 D}$ が小 さく, 一方, $L_{k} / D$ が大きい場合は, 危険断面で曲げモ一メ ントが卓越し充填コンクリートによって中立軸が曲げ圧 縮縁によるためやはり $A_{2 D}$ が小さくなる.

図22に示すように，吸収エネルギーW $W$ は, $n_{c}$ と同様に $L_{k} / D$ が10程度でもっとも小さい，図23は, 無次元化吸 収エネルギー $W /\left(N_{y} \delta_{y}\right)$ については, 短柱 $\left(L_{k} / D=5\right)$ では, 実験結果之同様に, 径厚比が20で200以上, 30 で 100以上, 50 では 100 程度が期待できるが, $L_{k} / D$ が10程度に増大 する間に急速に減少することを示している.

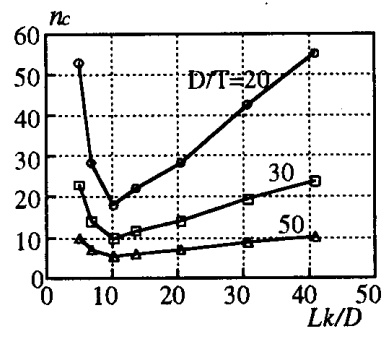

(a) 軸変位振幅 $2 \%$

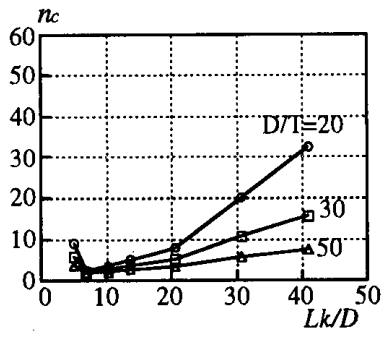

(b) 軸変位振幅 $4 \%$

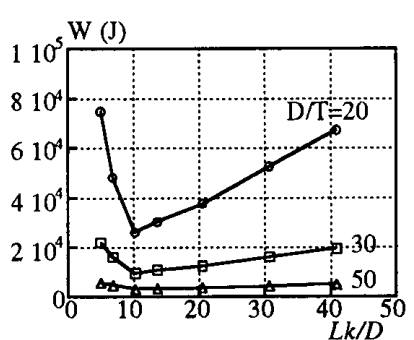

(a) 軸変位振幅 $2 \%$

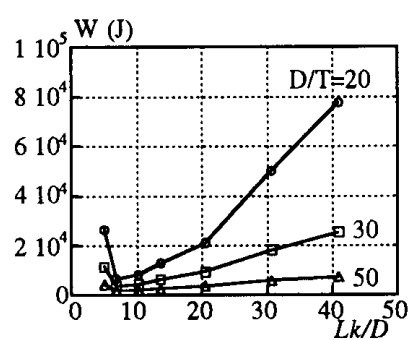

(b) 軸変位振幅 $4 \%$ 図22 吸収エネルギーと座屈長さ

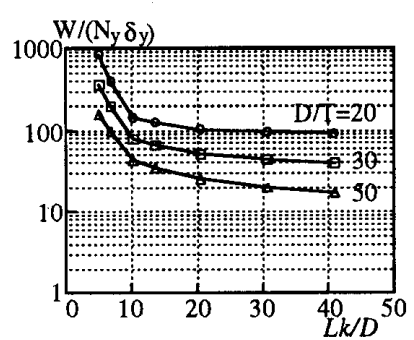

(a) 軸変位振幅 $2 \%$

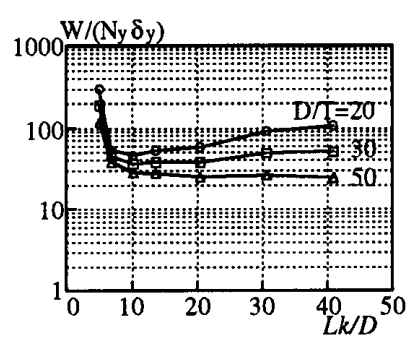

(b) 軸変位振幅 $4 \%$

\section{図23 無次元化吸収エネルギーと座屈長さ}

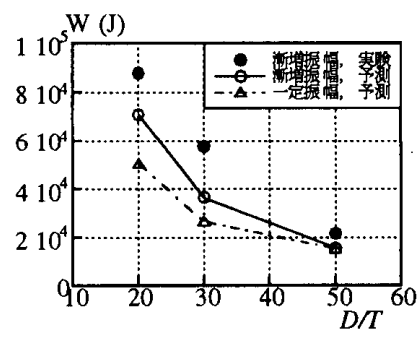

(a) 径厚比の影響

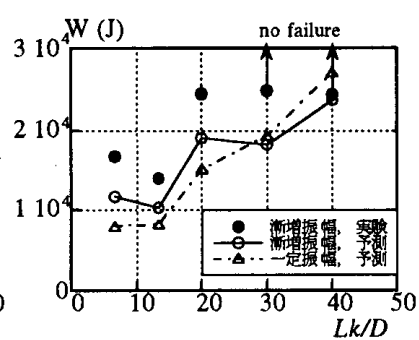

(b) 座届長さの影響 
図24(a)は, 外径が $101.6 \mathrm{~mm} て ゙ L_{k} / D$ が 10の試験体に ついて, 漸増変位振幅の場合の吸収エネルギ一の実験値 と予測值, および一定変位振幅の場合の予測値を示して いる. 径厚比が 20 と30は軸変位振幅が $3 \%$ のとき，50は 2\%のときに破断した. 一定変位振幅の予測値は, 破断時 の振幅レベルで繰返した結果である. 図24(b)は, 外径 が60.5mmで径厚比が30の試験体について, 図(a)と同様 な比較を行っている. 図より, 漸増変位振幅でのエネル ギ一吸収量の予測値は, 一定変位振幅の予測値より大き いか等しい，実験値はこれらを上回っている. 図より， 漸增変位振幅の場合の吸収エネルギーは, 破断時の軸変 位振幅レベルで一定に繰返された場合の予測値でほぼ安 全側に評価できると言える.

\section{6. 結論}

冷間成形鋼管にコンクリートを充填した部材を繰返し 軸方向力を受ける耐震要素として用いる場合の性能を調 べる目的で, これに正負交番の軸変位振幅を与える実験 を行い, 検討を加えて, 次の結論を得た.

(1) $L_{k} / D$ が 5 の短柱に $2 \%$ の軸変位振幅を与えた結 果, コンクリート充填によって, 局部座屈発生時期は大 差ないが，破断加力サイクル数および吸収エネルギーが 飛䠰的に増大する.

（2）局部座屈発生は, 軸変位振幅がごく小さいと遅い場 合があるが，一般に比較的早期である. しかし，破断ま でには多くの加カサイクルを必要とするので, コンクリ 一ト充填鋼管部材の終局限界を局部座屈発生時点とする のは不経済である.

（3）局部座屈を無視した解析によって,一定軸変位振幅 あるいは漸増軸変位振幅の載荷条件での軸方向挙動をお おむね予測できる。

（4）局部座屈後破断までの加力サイクル数は, 座屈長さ に無関係に，2D間縁変位振幅の関数になる. 実験結果 を基にこの関係式を提案した.

（5）加力サイクル当たりの吸収エネルギーと破断加力 サイクル数の積によって破断までの吸収エネルギーを予 測する方法を提案した。軸変位振幅がごく小さい場合を 除けば, 吸収エネルギーの実験値と予測値の比は, 平均 值 1.21 , 変動係数 $13.8 \%$ となった。 漸增軸変位振幅での 吸収エネルギーは, 破断時の軸変位振幅レベルを用いた 一定軸変位振幅の結果でほぼ安全側に評価できる.

（6）破断加力サイクル数および吸収エネルギーW は, $L_{k} / D$ が10 前後で最小になることが予測された. 無次元 化吸収エネルギー $W /\left(N_{y} \delta_{y}\right)$ は, 短柱 $\left(L_{k} / D=5\right)$ では, 径厚比が 20 で200以上, 30 で100以上, 50 では 100 程度が期 待できる. $L_{k} / D$ が大きいと, $W /\left(N_{y} \delta_{y}\right)$ は減少する.

\section{謝辞}

本研究は, 平成5，6年度文部省科学研究費補助金一般研 究 $\mathrm{B}$ (研究代表者: 松井千秋)によった. 実験では，久島 昭久, 有働文久, 浜辰夫各技官の協力を得た.(株)新日鐵, （株）日鐵建材からは良質の鋼管を提供頂いた（株)徳田 鉄工所には試験体を，(株)正栄にはピン支点装置を共に 高精度で製作頂いた．実験の遂行と結果の整理に大道寺 崇君の協力を得た.ここに深甚の謝意を表する.

注

1) 本論文の一部は, 文献17) 19)に発表済みである.

2) 理研精機（株）製の自動制御静的加力装置によった.

\section{参考文献}

1）松井千秋，河野昭彦：絽返し軸方向力を受けるコンクリート充填鋼管部材の 弹塑性性状に関する研究, 九州大学工学集報, 第60巻, 第6号, 1987.12,721728 .

2) A. Kawano and C. Matsui: An Experimental Study on Hysteretic Behaviour of Concrete Filled Tubular Members under Repeated Axial Loading, Proc. of Ninth World Conference on Earthquake Engineering, 1988.8, Tokyo-Kyoto, Vol. IV, IV133-138.

3) C. Matsui and A. Kawano: Strength and Behavior of Concrete-Filled Trusses, Proc. of The Second International Speciality Conference on Concrete-Filled Stee Tubular Structures, Science and Technology Exchange Center of Heilongjian Province, Harbin China, 1988.8, 113-119.

4) R.J.T Park: Seismic Performance of Steel-Encased Concrete Piles, Research Report, Department of Civil Engineering, University of Cantervery, NewZealand, 1987.5 .

5) S.G. Goel: Seismic Stability of Braced Steel Structures, SSRC Annual Technical Session Proceedings, 1986.4, 189-200.

6) S.G. Goel: Cyclic Load Behavior of Concrete-Filled Tubular Braces, Journal of Structural Engineering, Vol. 114, No. 7, ASCE, 1987.7, 1488-1506.

7) T. Matsumoto, M. Yamashita, Y. Murase, H. Harada, I Hashinaka, S. Sakamoto and T. Iida: Post-Buckling Behavior of Circular Tube Brace Under Cyclic Loadings, Proc. of International Meeting, Safety Criteria in Design of Tubular Structures, Tokyo, 1986.6, 15-25.

8) D.R. Sherman: Interpretive Discussion of Tubular Beam-Column Test Data, Dept. of Civil Engineering, University of Wisconsin-Milwaukee, 1980.12.

9）岩井哲, 朴錬洙, 野中泰二郎, 亀田弘行 : 山形䤡部材の極低壮イクル疲労破壤 実験, 日本建築学会棈造系論文報告集, 第445号, 1993.3,139-149.

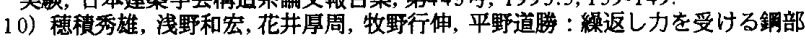
材の局部座屈断面に生じるき裂の発生に関する研究, 日本建築学会構造系論文 集, 第466号, 1994.12, 135-144.

11）桑村仁：紼返し塑性ひずみを受ける構造用鋼材の疲労-延性破壊罯移，日本 建築学会構造系論文集, 第461号, 1994.7, 123-131

12)河野昭彦，松井千秋，崎野良比呂，中島隆裕：軸引張塑性履歴がある銅管コ ンクリート部材の曲げ座屈荷重に関する実験的研究, 日本建築学会, 樥造工学 論文集, Vol. 39B, 1993.3, 335-342.

13) A. Kawano and R.F. Warner: Nonlinear Analysis of the Time-Dependent Behaviour of Reinforced Concrete Frames, Research Report No. R125, Dept. of Civil and Environmental Engineering. The University of Adelaide, 1995.1.

14) Popovics: A Numerical Approach to the Complete Stress-Strain Curves for Concrete, Cement and Concrete Research, 3(5), 1973.

15) Menegotto, M. and Pinto P.E.: Method of Analysis for Cyclically Loaded RC Frames Including Changes in Geometry and Non-Elastic Behaviour of Elements under Conbined Normal Force and Bending. IABSE Congress Reports of the Working Commission Band13, 1973.

16) M.A. Miner: Cumulative Damage in Fatigue, Journal of Applied Mechanics, Vol. 12, 1945, A159-164.

17）中島隆裕, 河野昭彦, 松井千秋 : 繰返し軸方向力を受けるコンクリート充嫔

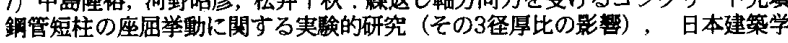
会大会学術犝演梗概集, 1993.9, 1745-1746.

18) 松井千秋，河野昭彦，高木潤一，大道寺崇，久島昭久：綎返し軸方向力を受け るコンクリート充填龬管部材の座㐿挙動と耐震性能に関する実駼的研究, 日本 建築学会九州支部研究報告, $1995.3,533-536$, その 1 短柱銅管部材の局部座羞

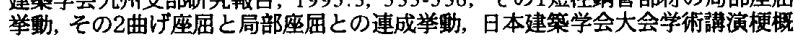
集, $1995.8,787.790$.

19）松井千秋（研究代表者）：繰返し軸方向力を受けるコンクリート充填龬管 部材の座屈举動と耐震性能に閏する研究。平成5，6年度科学研究費補助金一般 研究(B)研究成果報告書, 1995.3.

（1995年 9 月 10 日原稿受理，1995年12月 4 日採用決定） 